\title{
Independent Character Building of Special Needs Children in Special Elementary School
}

\author{
Rico Yuda Permana Putra*, Suyatno \\ Universitas Ahmad Dahlan \\ *Corresponding Author. Email: ricoyudha2104@gmail.com
}

\begin{abstract}
This study aims to describe the implementation of instilling independent character in SLB N 1 of Yogyakarta. The used research design was qualitative research using a case study. Data collection was conducted by interview, observation, and documentation. The collected data was analyzed using interactive-inductive analysis technique encompassed data reduction, data representation, and conclusion. The research result showed that (1) the indicator of independent character in SLB N 1 of Yogyakarta showed by preparing the need for studying, having self-confidence, individually finishing the assignments, being dare to express an opinion, group cooperation, reading and writing correctly also adequately., doing the calculation task independently. (2) Instilling independent character addressing special-needs students was carried out through learning activities, direct teaching, spontaneous activity, exemplary, and daily habituation. This finding can be used by stakeholders and inclusive educational practitioners to organize and conduct independent character building for special-needs students at school.
\end{abstract}

Article History

Received: 24-08-2021

Revised: 18-09-2021

Accepted: 08-11-2021

Published: 11-12-2021

Key Words:

Building Character, Independence, Special

Needs Student,

Special School.

How to Cite: Putra, R., \& Suyatno, S. (2021). Independent Character Building of Special Needs Children in Special Elementary School. Jurnal Kependidikan: Jurnal Hasil Penelitian dan Kajian Kepustakaan di Bidang Pendidikan, Pengajaran dan Pembelajaran, 7(4), 896-909. doi:https://doi.org/10.33394/jk.v7i4.4064

d.

https://doi.org/10.33394/jk.v7i4.4064

This is an open-access article under the CC-BY-SA License.

\section{Introduction}

The special-needs child is a child with a specific condition and different needs who need special attention over other children. The special-needs child has different traits: mental, sensor, physic, neurotic ability, social and emotional behavior, communication ability, and a modification of school assignments, learning methods, or potential development service (Nisa et al., 2018; Kristiana \& Widayanti, 2021; Mangunsong, 2009). Furthermore, special-needs children have equal rights to other children in life aspects and education (Lipkin \& Okamoto, 2015). The instruction for special-need children benefits from increasing their self-confidence appropriate for their intelligence, potential, and character without any exception.

The data showed that learning for special-needs children still have problems. The research of Sunanto and Hidayat (2017) explained that education for special-needs children consists of several factors; factor from school, like school unreadiness, especially classroom teacher and special assistant teacher to accompany children with disabilities; factor from parents playing a role to have the understanding of children with disabilities; and factor from the surrounding environment. In line with that, Putri and Taufan (2021) revealed that problems that occurred in learning for special-needs children are how many times are needed for achieving learning goals and other issues related to the application of principles in learning with special needs children. Meanwhile, the low self-confidence of students with disabilities also becomes a barrier to learning (Nida, 2018). Several strategies used in increasing learning success for special-needs children, for instance, has been shown in the research of Jannah et al. (2020), in which it showed that the use of information technology during online learning could make special-needs students have a new experience in using 
technology so that it can boost their self-confidence. Another finding explaining teacher's strategy to assist the learning for special-needs students focuses on 1) service for students that focused on the behavioral pattern of teachers to conduct educative interaction at school; 2) Curriculum adjustment aspect; 3) learning implementation aspect using the method of demonstration and habituation (Oktari et al., 2020).

One crucial aspect that needs to be considered in the educational process for specialneeds children is the cultivation of an independent character. The independent character is an important character for special-need children because it is a primary life ability and human need at the beginning of their age. By having independent character, special-needs children are expected to reach out minimal standard to carry out necessary activities like feeding, clothing, and toileting.

There are many strategies used to instill independent character to special-need children. Neli et al. (2020) mentioned two strategies of instilling independent character, explained as follows: first, separating children who have different emotional levels. For example, separating children who have gentle emotions and unruly children, the result in it make the condition better for students and teacher further can instill independent character over them. Second, giving responsibility and independence toward children so that they can adapt to the situation well. Independent character education can be seen through selfdevelopment, lesson integration, and school culture. Self-development consists of doing tasks individually, praying before and after learning individually. The lesson integration includes independent character education to syllabus and lesson plan in the school culture (Wening \& Hasanah, 2020) by creating a school situation that builds students' independence. Schmidt dan Vrhovnik (2015) said that teachers have a vital role in building special-need children's character. Therefore, the teacher's competence of special-needs children is required to be increased (Fakolade et al., 2009; Ismail et al., 2016) because during this time, the majority of the teacher's competence of special-needs children in the school where special-needs children learn is still low (Cooc, 2019).

Building a special-need student's independent character appropriate with life skill theory is the education of life skills. The life skill concept of the special-needs student of elementary school (9-13 years old) of independence can be achieved when students can help themselves and improve academic and functional academic skills. To conduct life skill theory, acquires appropriate methods with life skill concept. Alhairi (2015) said that the method used in character education to use well are (1) exemplary method, (2) Icon and affirmation method (stick and hand), (3) cooperative learning method, (4) habitation method, and (5) reward method (giving a reward).

Special-needs children need special treatment is caused by developmental disorders and abnormalities experienced. The disorders in special-needs children can be categorized in the aspects of physic/motoric, cognitive, language and speech, hearing, sight, social, and emotion (Mudjito, 2014). In line with that, Mangunsong (2009) stated that special-needs children are children who deviate from the average normal child in mental characteristics, the ability of sensory, physic, and neuromuscular, social and emotional behavior, communication skill, and school assignment modification from teachers, learning method, or potential development service. Of the two explanations above, it can be concluded that special-needs children are children who have unique characteristics that are different from other children in general, which is showed in mental, emotional, physical disabilities.

Special-needs children are caused by damage and disorders that affect the nervous system, such as the brain, spinal cord, and branches scattered in all parts of the human body. Irwanto et al. (2010) stated that factors caused disabilities based on the occurred period 
divided into three periods: prenatal, neonatal, and postnatal. First, in the prenatal period, disorder based on its period occurs in the development of the embryo, early fetus, and late fetus. Other causes are consumed medicine caused by congenital disabilities. Second, in the neonatal period, several factors that have caused congenital disorders since pregnancy birth are prematurity, children born with tools, abnormal baby position, or baby health. Third, several factors that caused newborn disabilities are wound infection, chemical materials, and malnutrition in the postnatal period. Other causes affected child after birth disorders caused seizures occurred frequently and long enough is caused the infection of the central nervous system, head trauma (caused by falls or hits on the head), brain tumors, and diarrhea to dehydration during infancy.

Despite having different necessities and characteristics, special-needs children have equal rights to access educational services like other children (Kauffman, 2018; Hornby, 2015; Galloway, 2018). Permendiknas Number 70 of 2009 Article 3 mentioned that every student who has physical, emotional, mental, and social disorders or is gifted intelligence has a right to participate in inclusive education in a specific education unit appropriate with their needs and ability. It showed that education is not only for normal children but also need for special-needs children. Inclusive education is an educational service system that required special-needs students to learn in the school and participated in the class together with their peers. Through inclusive students, special-needs children can optimize student's potential together with other children (Hodkinson, 2015). Therefore, the character in inclusive education must be instilled in special-needs children to face their future life. One of the traits conducted is by modifying school curriculum and learning materials to appropriate with all of the students' needs.

Independent character is one of the ability to carry out the task and daily activities and get the guidance from parents or teachers appropriate for child development stages (Desmita, 2009; Maryono et al., 2018). Special-needs children highly need independent character because they are the provisions to live in adolescence (Masriah et al., 2015). Special-needs children who have independent character, after graduating from school, are expected to be able to carry out their daily life and finishing assignment by themselves without everyone's help. For example, doing homework, doing homework without any help from friends, looking for learning sources, preparing school kits, being able to pray by themselves, etc. Specialneeds children who have independent character is expected to be able to work as other people do.

Instilling independent character in the school is expected to educate the children to be independent without help from other people and solve their encountered problems. Ali and Asrori (2008) explained that independence divided into several related types and mutually complete one to another type. This type encompasses emotional independence, behavioral independence, value independence. First, Emotional independence is an independent dimension related to changes that affect adolescent emotional relationships with other people, especially with their parents. Emotional independence can be defined as a child's ability not to depend on people's emotional support, especially their parents. The fact that the loss of emotional ties between children and parents during childhood occurs very quickly. The more people grow up, the better they treat themselves. Second, behavioral independence is an independent dimension referring to a child's ability to choose freely. The children in this dimension can freely and not influence other parties to decide the choice and decisions, but they still need other advice to support them. Budiman (2006: 89) explained three domains of developed behavioral independence over infants and adolescents. Firstly, they can make the decisions signed by the awareness demeanor of the risk of their behavior, choose the 
alternative problem solving based on their consideration of other people, and be responsible for their decisions. Secondly, they have the power to influence other parties that are signed by the demeanor of unsusceptible to peer and parent pressure in making the decisions and involve in a social community without any pressure. Thirdly, they have self-confidence signed by the ability to fulfill daily needs, responsibility, solve the problem, and dare express the idea or opinion. Forth, in value independent, value independent is the independence referring to the ability to interpret the principles of right and wrong and unimportant. The value independence generally occurs through the process of internalization, which is usually unrealized. By this value independence, children can refuse the pressure from other people regarding values. The development of value independence takes place in late adolescence or young adulthood.

The special school of SLB N 1 of Yogyakarta is one of the schools that special-needs students learn. The problems encountered by teachers of SLB N 1 Yogyakarta consists of many aspects, such as various special-needs child ability, background diversities of student's family which leading to the program supported insufficiently, most of the teachers' educational background is not supporting the assistantship of special-needs children so that the school system must be repaired in order to keep the increase of teacher's knowledge and skills to assist learning for special-needs children. School vision and programs, furthermore, help to implement character education for special-needs children. One of the stresses in the learning process is to develop independence potential optimally of special-needs children. For example, the stresses that appear in the school's planned vision are to achieve special education of independence aimed to achieve independent student and exceptional service. To achieve the vision, schools have equipped teachers with qualified pedagogical and professional competencies, good classroom management, and skills in implementing appropriate strategies for building independent character. Based on described background, this research aims to describe independent character indicators and teacher's strategies in building the independent character of special-needs children of SLB N 1 Yogyakarta. The research findings are expected to benefit stakeholders and practitioners of inclusive education to plan independent character building for special-needs children in the school.

\section{Research Method}

This research used qualitative research with a case study approach (Creswell, 2013). Qualitative research is the research conducted to describe and explain factually, systematically, accurately regarding specific facts and populations (Sanjaya, 2013). A case study approach used for this research is because the events studied are contemporary and have a natural setting, and the researcher does not intervene with the research subject (Gomm, Hammersley \& Foster, 2000; Noor, 2008). Data collection in a case study approach attempts to combine data obtained from various sources (Yin, 2006; Song et al., 2016; Denzin \& Lincoln, 2011). This research place was located in state special school 1 of Yogyakarta, known as SLB N 1 of Yogyakarta, in the elementary school of 2020/2021 odd school year.

The subjects of the research were the principal and classroom teacher of SLB N 1 of Yogyakarta. Data collection techniques were (1) interviews with the principal and classroom teachers of grades I, II, and VI, and (2) documentation of motto, vision, mission, and purposive of the school of SLB N 1 Yogyakarta. The instruments of data collection were interview and documentation guidelines. Data validity used in this research were (1) source triangulation that used to know the correctness of certain information from various obtained data sources, and (2) method triangulation that used to check data validity through research 
findings and used method in the data collection. The data analysis technique used encompassed data collection stages, data reduction, data display, and concluding (Huberman \& Miles, 2019).

\section{Results and Discussion}

The research result was presented based on themes found by the researcher in analyzing data in the field. Those themes were chosen according to the needs of answering problem formulation. Based on the indicators of the independent character of special-needs students, it was found six main themes as follows: able to prepare the learning needs, be selfconfidence, finish an assignment individually, be brave to express the opinion, able to cooperate in the group, read and write properly and correctly, able to do calculation task individually. Meanwhile, the strategy of instilling independent character in SLB N 1 of Yogyakarta was found four main themes: learning activities, direct guidance, exemplary, and habituation.

\section{Indicators of Independent Character of Special-Needs Children in SLB N 1 of Yogyakarta}

The theory of lifestyle education guides the researchers in Law Number 20 of 2003 about the National Education System To describe special-needs children's independent character indicators. Several indicators show the Independent character of special-needs children: first, having survival skills to prepare learning necessities in the school and not feel inferior. Second, having academic skills like finishing their assignments individually, being brave to express an opinion, and cooperating in the group. Third, having functional academic skills like reading, writing and capable of doing calculation tasks individually.

\section{1) Capable to Prepare Learning Necessities}

According to the ability to prepare a child's learning necessities by itself, most special-needs children in SLB N 1 of Yogyakarta have been able to carry out, and others still need the teachers' and parents' help. Based on the researcher's interview result with teachers, it had been said that most of the students are capable of preparing their learning necessities like preparing the books for school. Meanwhile, other students still need the help of the teachers and parents in preparing their learning needs. For students grade I, they are still incapable of preparing their learning needs, while the parents have a big role in rechecking what students have prepared when going to school. According to the interview result with SL, classroom teacher of grade VI, SL said that:

Students can prepare their learning necessities by themselves, like preparing books for school. While sometimes their parents recheck students' needs before going to school to avoid forgetting their main learning needs" (interview with classroom teacher of grade VI, SLB N 1 of Yogyakarta on July 22, 2020).

\section{2) The demeanor to feel Inferior (Self-Confidence)}

Several students have felt inferior to their friends, teachers, principal, and society. According to the teacher's interview, the researcher found that most special-needs children in SLB N 1 of Yogyakarta have felt confident. Special-needs children did not feel inferior while meeting their friends or teacher in the school. However, several students do not feel that way, which they are still embarrassing while meeting other students or when the teachers asked to come forward, that usually, they do not want to come forward and choose to stay in place. According to the interview result with FA, teacher of grade II, SA said that:

Usually, the students have been brave and did not feel inferior with other students or the other teacher outside grade II teachers. Sometimes several students want to talk or communicate with their classroom teachers only. There are just one or two students 
who are brave to come forward, and the students who do not want do not become confident of themselves (Interview with teacher grade II, SLB N 1 of Yogyakarta on July 22, 2020).

According to the interview result with RA, classroom teacher of grade I, RA said that:

Special-needs students usually do not feel inferior or feel confident while meeting their friends in the school. However, they do something is according to their mood. For coming forward while learning in the class, special-needs students of grade I usually still embarrassed, especially when the teacher asked them to come forward. If students are held by and persuaded by the teacher to come forward, the students usually immediately want to come forward (Interview with classroom teacher grade I, SLB N 1 of Yogyakarta on July 22, 2020).

\section{3) Capable to Finish Assignments Individually}

Special-needs children's ability to finish assignments individually given by the teacher, as the success of instilling independent character, can be said success, but they still need guidance. However, many special-needs students can finish assignments given by the teacher when teaching in the class. Based on the interview result, it was found that most special-needs students can finish the task even though they still need the teacher to guide them. Regarding homework, special-needs students sometimes forget to do it; otherwise, they need help from their parents. According to the interview result, the classroom teacher of grade II, Mrs. FA, said that:

Students can finish the assignments given by the teacher, but sometimes still need direct guidance from the teacher. Some students forgot to finish their homework, but others could finish their tasks individually. Besides, some students also needed the help from their parents" (interview with classroom teacher grade II, SLB N 1 of Yogyakarta).

\section{4) Being Brave to Express The Opinion}

The ability of special-needs students in SLB N 1 of Yogyakarta regarding expressing the opinion, as the success of instilling independent character, can be said unsuccessful because some students are still incapable of expressing their opinion, unlike some other students who had been brave to express what was in their minds.

Based on the interview conducted by the researcher and teacher of SLB N 1 of Yogyakarta, it was found that only one or two students were brave to express the opinion in front of other people. Although they were brave, sometimes they were still embarrassed to talk. However, special-needs students of grade I still could not express their minds due to their condition. The first-grade special-needs students are still shy about going to school; they sometimes still have to be waited on by their parents. According to the interview result, the classroom teacher of grade I, RA, said that:

The first-grade special-needs students were still not incapable of expressing the idea due to their condition. The first-grade special-needs students were still waited by their parents because they were shy to go to school alone (Interview with classroom teacher of grade I, SLB N 1 of Yogyakarta on July 22, 2020).

\section{5) Capable to Cooperate in Group}

The ability of special-needs students to cooperate in the group in SLB N 1 of Yogyakarta, as the success of instilling independent character, can be said still unsuccessful, it is caused by the lack of giving group assignment for special-needs students of SLB N 1 of Yogyakarta while learning process. According to the researcher's interview result to the teacher of SLB N 1 of Yogyakarta, it was found that students could not cooperate in the group because the teacher did not give group assignments for special-needs students. The 
teacher does not give assignments in groups to students with special needs because their abilities and characteristics are different. After all, the types of assignments given to the students are also different. While the teacher gives group assignment, it requires extra guidance in its implementation. Based on the interview result with Mrs. SL, a classroom teacher of grade VI, Mrs. SL stated that:

Teacher does not give the assignment in groups, because the ability and characteristics of special-needs students are different ones to another. Furthermore, the teacher gives the different assignment accord to their ability and characteristics (Interview with classroom teacher of grade VI, SLB N 1 of Yogyakarta).

\section{6) Capable to Read and Write Properly and Correctly}

As the success of instilling independent character in SLB N 1 of Yogyakarta, specialneeds students' ability to read and write properly and correctly can still be said unsuccessfully. Due to the lack of the students' ability to read and write, students still require teacher guidance while carrying out class learning. Based on the interview result conducted by the researcher with the teacher of SLB N 1 of Yogyakarta, it was found that special-needs students can read and write, but not fluently. The teacher also said that, despite can read and write, the students are still slow reader and writer, in which teacher directly need to guide the special-needs students and teach them to read and write properly and correctly. Based on the interview result with Mrs. FA, a classroom of grade II, she said that:

Students can read and write, even though the reading and writing are not yet fluent. For this matter, students can read and write by themselves, but the teacher still leads them to slowly write and read (Interview with classroom teacher of grade II, SLB N 1 of Yogyakarta on July 22, 2020).

\section{7) Doing Calculation Tasks Independently}

As the success of instilling independent character in SLB N 1 of Yogyakarta, specialneeds students' ability to do calculation tasks independently can still be said unsuccessfully. In its implementation, the students often ask and need direct guidance from the teacher. Based on the interview result conducted by the researcher with the teacher of SLB N 1 of Yogyakarta, it was found that special-needs students specifically could not do calculation tasks given by the teacher because they still asked their teacher regarding how to do the task. Some students can do calculation task but depend on the questions given. If it includes the simple question, special-needs students can do it by themselves, even though sometimes they still need teacher guidance. In the interview, Mrs. FA said that:

Regarding on calculation task, if the task consisted of the simple question, specialneeds children can do it by themselves, although sometimes they asked the teacher for guidance. Usually, they asked their friend to answer or directly asked the teacher about the question's answer (Interview with classroom teacher of grade II, SLB N 1 of Yogyakarta on July 22, 2020).

\section{The Strategy of Instilling Independent Character in SLB N 1 of Yogyakarta 1) Through Learning Activity}

SLB N 1 of Yogyakarta has been implemented character education in the class learning process. Data collection showed that independent character education through learning activity, as one of the conducted strategies. Teachers are instilling independent character to their students, for example, by prohibiting them from cheating or asking their friend the question's answer. Learning begins with teacher instruction to students to independently carry out activities, like eating individually during break time. In this case, the teacher relates every learning with the importance of independent character. For example, in 
the civics lesson of Pancasila, the teacher gives an example verbally or practically toward Pancasila's principle containing character education. Through the interview, SL stated that: Instilling character education in the class relates every lesson with character education, especially the character of independence. For example, in the civics lesson of Pancasila, the teacher gives an example verbally or practically toward Pancasila's principle containing character education. The teacher used media, but it depends on the situation. Using media, the student can directly see the visual example from the video that contains the implementation of character education, especially independent character or related to independence (Interview with classroom teacher of grade IV on July 22, 2020).

Meanwhile, the principal said that instilling independent character can be carried out through learning activities by improving routine activities, for example, carrying out independent activities for every student. Simultaneously, the school attempts to include character education in learning materials, and teachers can relate it to character education, especially independent character.

\section{2) Through Direct Guidance}

Direct guidance is a strategy used for instilling independent character to special-needs students. In SLB N 1 of Yogyakarta, direct guidance to students is carried out by the teacher and is already going well. Direct guidance is not only used verbal but also uses media to carry out direct guidance. The abovementioned statement obtained from the interview of $\mathrm{S}$, a principal of SLB N 1 of Yogyakarta, S said that:

The school implements character education through direct guidance to students with special needs when learning in class. Every classroom teacher was carried out the task to implement direct education to the students (interview with the principal of SLB N 1 of Yogyakarta on July 21, 2020).

Based on the interview result conducted with the teacher, direct guidance given is to provide direct examples of the activities related to independent character, that students are expected to imitate that behavior. Not only exemplifying directly to the students but also directly explains the students regarding independent character to practice it immediately; simultaneously, the activities are routinely a habit for students. The guidance process also requires the right time, such as when students make mistakes, during the learning process, or during break time. Regarding media use in the direct guidance process, the teacher uses video or the media appropriate for students' needs.

\section{3) Through Spontaneous Activity}

Spontaneous activity is an activity that can be carried out without limitation to habituate politeness and other praiseworthy. Teachers have implemented the strategy of instilling independent character to students of SLB N 1 of Yogyakarta well. Teacher conducted spontaneous activity is aimed that the students can carry out independent activities properly and correctly.

According to the teacher of SLB N 1 of Yogyakarta's interview result, the teachers usually carry out a spontaneous activity when students make mistakes, and the teacher spontaneously confirms it. Spontaneous activity that the teachers usually carry out exemplifying students with daily independent character. Other activities carried out in spontaneous activity are like spontaneously sweeping up the trash, while with this activity the students usually students will help or replace doing that activity. The teacher aims to carry out that activity because they can imitate and practice what they have seen in their daily lives. Through the interview, FA stated that: 
Spontaneous activity that the teachers usually carry out in front of the students is when they make mistakes, and teacher spontaneously confirms it and exemplifies the right way. Giving the spontaneous activity is by giving the students the example of an independent character's behavior in daily life. The student usually pays attention directly to what the teacher is doing when doing spontaneous activities (interview with grade II classroom teacher of SLB N 1 of Yogyakarta on July 22, 2020).

\section{4) Through Exemplary}

Providing the example is a strategy to instill independent character for special-needs students in SLB N 1 of Yogyakarta at the elementary school level. In this school, the teacher has given the exemplary related to an independent character that aimed to motivate students to live independently. Based on the interview result with teachers in SLB N 1 of Yogyakarta related to exemplary as a strategy to instill independent character for special-needs students, the teacher provides examples of the behaviors that reflect independent character to students the instruction in the class. The teacher also briefs students about exemplary, carried out continuously and repeatedly to understand the characteristics of independence or related to independence. Through the interview, FA said that:

The exemplary provided by teachers to the students is by providing the examples of behaviors that reflect the activity related to independent character, like preparing books that used while learning process (interview with a teacher of grade II, SLB N 1 of Yogyakarta on July 22, 2020).

Teachers' another way to instill independent character through exemplary is by telling the story to students related to independence in the surrounding environment, which expects them to imitate that example of independence. However, in providing exemplary examples, teachers usually experience the obstacles. The obstacles experienced by teachers are the lack of student's understanding of the example provided by teachers. Thus teachers need to repeat the exemplary until the students understand well what the teachers said.

\section{5) Daily Habituation}

Based on the interview result with teachers in SLB N 1 of Yogyakarta, the teacher carries out independent character habituation by morning praying together, preparing students' learning needs individually. Another way teachers exemplify is by inviting the students to habituate independent activity routinely, the result in it can form a new good habit for students. The teacher also explains to students daily habituation related to the independent character; consequently, students can imitate exemplary activity. Through the interview, RA said that:

Teachers carry out daily picket like throwing the trash into the provided trash can and erasing the writing materials on the whiteboard after studying. Teachers invited the student to conduct independent activity routinely everyday, like praying by themselves according to their belief (interview of grade I teacher in SLB N 1 of Yogyakarta, on July 22, 2020).

The principal also said that teachers and students have implemented independent character routinely and carried out in the school every day, such as praying individually and orderly.

\section{Discussion}

This study aims to describe two important discussions: first, the indicators of the independent character of special-needs students, and second, teacher's strategy to build independent character education to special-needs students of SLB N 1 of Yogyakarta. Based on the data analysis, it was found vital findings of this research as follows: first, student's independent characters of special-needs students of SLB N 1 of Yogyakarta were showed in 
six indicators; able to prepare learning necessities, do not feel inferior (self-confidence), finish assignments individually, brave to express the opinion, able to cooperate in groups, able to read and write properly and correctly, and do calculation task individually. The ability of special-needs students to prepare learning necessities is an indicator of independent character. When preparing learning necessities in the home, parents monitor their children with their necessities by recheck what students have prepared. While in the school, teachers monitor the students in preparing learning needs before learning begins. This research result strengthens the research of Anggriana and Trisnani (2016). A child's ability to implement the activities must be monitored and guided directly by teachers. It is due to the lack of the special-needs children's ability to prepare something individually.

The ability of special-needs students not to feel inferior can be said successful in building independent character. Some students are brave, and others have been brave to interact with their friends and teachers in the school. Some students are also brave to come forward, although they are still shy and require the teacher's guidance. This study's results complement Amaliyah's (2017) research stating that factors that build self-confidence in students with special needs are family, students' ability, and success. A strong desire and determination are things that can foster a confident attitude toward children with special needs. This research found that feeling of inferiority arises from student's self.

Students' ability to complete assignments individually can be said successful because this special-needs student's ability can be completely carried out by the students, even though sometimes they still need direct teacher's guidance. Besides, the homework of special-needs students has been completed aside from the help of the parents. The research result of Husna (2017) stated that finishing individual tasks will make a habit for special-needs students and become a habit when carried out repeatedly. Therefore, it leads the student to be more independent.

The ability to finish group tasks and express the opinion can be said still unsuccessful. It is caused the first-grade students who could not complete group tasks. Because of the students' inability, the teacher did not give them group tasks, which is also led to different abilities and characteristics of the students. Most students are not brave to express their opinion, and it is likely caused by the characteristics and conditions of special-needs students. This research is in line with Riadin dan Usop's (2017) research stating that special-needs children have significantly different characteristics, either interindividual or intraindividual. Thus, it makes students difficult to interact with their surrounding environment to develop their potential in education and instruction.

The ability to read and write correctly can be said unsuccessful in building specific independent characters. Many special-needs students can not yet read and write properly and correctly. They truly still need guidance from teachers to read and write. This research has completed the research of Maulida et al. (2019) stated that reading ability for special-needs students requires several stages that teachers must emphasize, such as using the structural analytic-synthetic (SAS) method on the reading ability of students with special needs.

The ability to do calculation tasks individually is still unsuccessful. Most students have not been able to complete the calculation questions given by the teacher. However, if they are given simple questions like addition problems, they can solve them under teachers' direct guidance. This research result differs from Hadi's (2014) research that specific media and approaches can solve students' difficulty in mathematics to help students not feel bored while solving simple addition problems. In general, this research result is in line with the previous findings, character building of special-needs students emphasizes the well and sustainable cooperation between school and parents in the home (Palareti et al., 2016; 
Ammari \& Schoenebeck, 2015; Lavan et al., 2019; Petcharat \& Liehr, 2017; Siddiqua \& Janus, 2017; Shenaar-Golan, 2017).

The second finding is independent character building that can be manifested using a good strategy to instill the independent character to special-needs students. The research result showed five school strategies to instill independent characters towards special-needs students; learning activity, direct guidance, spontaneous activity, exemplary, and habituation. The integration of building independent character is the main strategy carried out by the school. Due to this strategy, the result is that teachers are involved in building character education. It is in line with the research finding of Suyatno et al. (2019), which stated that the success of character education in schools must be supported by all teachers' contributions, regardless of the subject being taught.

The second strategy is through direct guidance. Through direct guidance, the teacher gives direct examples to students by actions conducted continuously related to independent character. It is expected that students can do the exemplified actions and develop themselves optimally and need the right time to carry out direct guidance. This study completed Rofiah (2015) research, which stated that Direct guidance is a continuous process of activity, takes place continuously, and is not an instantaneous or accidental activity. A systematic, structured, and well-planned goal achievement develops a conducive environment for students' development, provides encouragement and motivation, builds bravery in responsible actions, develops the ability, substitutes the behavior, and is independent.

The third strategy is spontaneous activity. Teachers carry out the spontaneous activity by aiming that students can directly imitate and carry out a spontaneous independent activity like sweeping the class floor, helping each other, cooperating, and guiding students who make mistakes. The research result is in line with Wibowo's (2012) statement, which stated that spontaneous activities are carried out when the teacher finds out that a student's bad behavior must be corrected at that time. For example, when a student is littering or disturbing their friends, teachers can directly admonish that student and confirm their mistakes.

The fourth strategy is providing exemplary. Exemplary aimed to motivate students to live independently. Teachers can provide the exemplary through several actions, such as providing examples of the actions that reflect the independent character, guiding students, and telling a story about the exemplary related to independence. This finding is in line with Gunawan's (2014) research, which stated that teachers must provide an exemplary example in good actions to be an example for students. Teachers who are expected their students to act and behave appropriately with character and cultural values must be the first to provide the example of behavior and attitude appropriate to these values.

The last strategy is habituation. Daily habituation carried out by school residents, like principals, teachers, students, and academic staff, is by individually praying based on their belief, and it is the ritual morning that must be conducted by school residents, helping to throw garbage in its place, and erasing whiteboard. All of these activities aimed to build good routine activities, especially for special-needs students. The research result is similar to Gunawan's (2014) statement, habituation is the action that is deliberately carried out repeatedly to become a habit, and the application of the habituation is related to practice because what is habituated is something that is practiced and becomes the core of the habit of routine repetition.

\section{Conclusion}

To be concluded in this study, there are two important discussions: first, the indicators of the independent character of special-needs students in SLB N 1 of Yogyakarta consist of student 
ability to prepare the learning necessities, the ability to finish assignments individually, the ability to express the opinions that only several students who are brave to do it under teacher's guidance, not feeling inferior resulting in students who are brave to interact with teachers and their friends, the ability to read and write, and the ability to solve simple calculation tasks. Second, the strategy of building character in SLB N 1 of Yogyakarta is carried out through the integration of learning, exemplary, direct guidance, routine activities, and daily habituation. Forming independent character is supported by good communication between teachers and students, among peers in the school, and school vision emphasized independent character formation. In communication, teachers guide students by directing and instructing clearly. The interaction among peers is carried out by supporting each other, helping each other, and cooperating, and even a student becomes a mentor for other students. Various abovementioned aspects are supported by the vision of a school-oriented to the development of student independence.

\section{Recommendation}

According to the research result, this finding suggests two outcomes that can be implemented. Firstly, the success of independent character building for special-needs students requires cooperation from many parties like school, teachers, and parents. To that, a particular school or and inclusive school supposedly needs a cooperative program involving parties systematically. Secondly, determining the school vision that is hospitable for the needs of special-needs students becomes the priority for all of the educational implementation of special-needs students. The decision of the vision will affect programs developed by the school.

\section{References}

Alhairi. (2015). Penanaman Pendidikan Karakter Bagi Siswa Berkebutuhan Khusus "Tunagrahita” di SMALB Negeri 1 Yogyakarta. UIN Sunan Kalijaga.

Ammari, T., \& Schoenebeck, S. (2015). Networked empowerment on facebook among parents of children with special needs. Conference on Human Factors in Computing Systems - Proceedings, 2015-April(July), 2805-2814. https://doi.org/10.1145/2702123.2702324

Anggriana, T. M., \& Trisnani, R. P. (2016). Kompetensi Guru Pendamping Siswa Abk Di Sekolah Dasar. Jurnal Konseling Gusjigang, 2(2), 157-164. https://doi.org/10.24176/jkg.v2i2.702

Cooc, N. (2019). Teaching students with special needs: International trends in school capacity and the need for teacher professional development. Teaching and Teacher Education, 83, 27-41. https://doi.org/10.1016/j.tate.2019.03.021

Creswell, J. W. (2013). Qualitative inquiry and research design: Choosing among five approaches (3rd ed.). Sage.

Denzin, N. K., \& Lincoln, Y. S. (Eds. . (2011). The SAGE handbook of qualitative research. Sage.

Fakolade, O. ., Adeniyi, S. ., \& Tella, A. (2009). Attitude of teachers towards the inclusion of special needs in general education classrooms:the case of teachers in some selected schools in Nigeria. International Electronic Journal of Elementary Education, 1(3), 157-169.

Gomm, R., Hammersley M., \& Foster, P. (Eds. ). (2000). Case study method. Key issues, key texts. Sage.

Gunawan, H. (2014). Pendidikan Karakter Konsep dan Impelentasi. Alfabeta. 
Huberman, A. M., \& Miles, J. S. M. B. (2019). Qualitative data analysis: A methods sourcebook.

Husna, L. (2017). Pendidikan Karakter Mandiri pada Siswa Kelas IV SD Unggulan Aisyiyah Bantul. Jurnal Pendidikan Guru Sekolah Dasar, 6(10), 964-974.

Ismail, Z., Basheer, I., \& Khan, J. H. (2016). Teachers' Attitudes towards Inclusion of Special Needs Children into Primary Level Mainstream Schools in Karachi. The European Journal of Social and Behavioural Sciences, 17(3), 2177-2196. https://doi.org/10.15405/ejsbs.195

Jannah, R. N., Wulandari, N. L., \& Budi, S. (2020). Pengalaman Belajar Daring Siswa Berkebutuhan Khusus pada Pandemi COVID-19 di SD Inklusif. Elementary Islamic Teacher Journal, 8(2), 359-376.

Kristiana, I. F., \& Widayanti, C. G. (2021). Buku ajar psikologi anak berkebutuhan khusus.

Lavan, A., Reiter, S., \& Heiman, T. (2019). Educational Involvement of Parents of Mainstreamed Special Needs Children. Contemporary School Psychology, 23(4), 401-411. https://doi.org/10.1007/s40688-018-0202-1

Lipkin, P. H., \& Okamoto, J. (2015). The individuals with disabilities education act (IDEA) for children with special educational needs. Pediatrics, 136(6), e1650-e1662. https://doi.org/10.1542/peds.2015-3409

Mangunsong, F. (2009). Psikologi dan Pendidikan Anak Berkebutuhan Khusus Jilid I. Lembaga Pengembangan Sarana Pengukuran dan Pendidikan Psikologi (LPSP3) UI.

Maulida, N. B., Ajriyah, K. F., \& Budiman Yeni, M. A. (2019). Studi Kasus Penanganan Kesulitan Membaca Siswa ABK Kelas 3 SD Negeri Poncol 03 Pekalongan dengan Metode Struktural Analitik Sintetik (SAS). Jurnal Ilmiah Sekolah Dasar, 3(4), 560. https://doi.org/10.23887/jisd.v3i4.23035

Neli, M., Indrawadi, J., \& Isnarmi. (2020). Penguatan Pendidikan Karakter Mandiri Anak Berkebutuhan Khusus Tunagrahita di Panti Sosial Bina Grahita "Harapan Ibu" Padang. Journal of Civic Education, 3(2), 172-177.

Nida, F. L. K. (2018). Membangun Konsep Diri Bagi Anak Berkebutuhan Khusus. ThufuLA: Jurnal Inovasi Pendidikan Guru Raudhatul Athfal, 2(1), 45-64.

Nisa, K., Mambela, S., \& Badiah, L. I. (2018). Karakteristik Dan Kebutuhan Anak Berkebutuhan Khusus. Jurnal Abadimas Adi Buana, 2(1), 33-40.

Noor, K. B. M. (2008). Case study; A strategic research methodology. American Journal of Applied Sciences, 5(11), 1602-1604.

Oktari, W., Harmi, H., \& Wanto, D. (2020). Strategi Guru Dalam Pembelajaran PAI Pada Anak Berkebutuhan Khusus. TA'DIBUNA: Jurnal Pendidikan Agama Islam, 3(1), $13-28$.

Palareti, G., Legnani, C., Cosmi, B., Antonucci, E., Erba, N., Poli, D., Testa, S., \& Tosetto, A. (2016). Comparison between different D-Dimer cutoff values to assess the individual risk of recurrent venous thromboembolism: Analysis of results obtained in the DULCIS study. International Journal of Laboratory Hematology, 38(1), 42-49. https://doi.org/10.1111/ijlh.12426

Petcharat, M., \& Liehr, P. (2017). Mindfulness training for parents of children with special needs: Guidance for nurses in mental health practice. Journal of Child and Adolescent Psychiatric Nursing, 30(1), 35-46. https://doi.org/10.1111/jcap.12169

Putri, S. N. A., \& Taufan, J. (2021). Permasalahan Dalam Pembelajaran Selama Pandemi Covid-19 Bagi Anak Berkebutuhan Khusus. Jurnal Penelitian Pendidikan Khusus, 9(2). 
Sanjaya, W. (2013). Penelitian Pendidikan: Jenis, Metode dan Prosedur. Kencana Prenada Media Group.

Schmidt, M., \& Vrhovnik, K. (2015). Attitudes of teachers towards the inclusion of children with special needs in primary and secondary schools. Hrvatska Revija Za Rehabilitacijska Istrazivanja, 51(2), 16-30.

Shenaar-Golan, V. (2017). Hope and subjective well-being among parents of children with special needs. Child and Family Social Work, 22(1), 306-316. https://doi.org/10.1111/cfs.12241

Siddiqua, A., \& Janus, M. (2017). Experiences of parents of children with special needs at school entry: a mixed method approach. Child: Care, Health and Development, 43(4), 566-576. https://doi.org/10.1111/cch.12443

Song, J. F., Li, S. Z., Zhou, R. S., Shao, J., Qiu, X. M., Jia, Y. Y., Wang, J., \& Zhang, X. (2016). Three novel Cu6S6 cluster-based coordination compounds: Synthesis, framework modulation and the sensing of small molecules and $\mathrm{Fe} 3+$ ions. Dalton Transactions, 45(29), 11883-11891. https://doi.org/10.1039/c6dt02264b

Sunanto, J., \& Hidayat, H. (2017). Desain Pembelajaran Anak Berkebutuhan Khusus dalam Kelas Inklusif. Jassi Anakku, 17(1), 47-55.

Wibowo. (2012). Manajeman Kinerja (Edisi ke 3). Rajawali Pers.

Yin, R. K. (2006). Case study methods. In In: J.L. Green, G. Camilli, \& P. B. Elmore (Eds.), Handbook of complementary methods on educational research. (pp. 111-122). American Educational Research Association. 